\section{Australian Journal of Crop Science}

AJCS

ISSN:1835-2707

AJCS 14(03):485-494 (2020)

doi: 10.21475/ajcs.20.14.03.p2144

\title{
Conventional breeding of potatoes for resistance to bacterial wilt (Ralstonia solanacearum): Any light in the horizon?
}

\author{
Jane Muthoni ${ }^{1 *}$, Hussein Shimelis ${ }^{2}$, Rob Melis ${ }^{2}$ \\ ${ }^{1}$ Kenya Agricultural and Livestock Research Organization (KALRO), Kenya \\ ${ }^{2}$ African Centre for Crop Improvement, University of KwaZulu-Natal, College of Agriculture, Engineering and \\ Science, School of Agricultural, Earth and Environmental Sciences, Private Bag X01, Scottsxille 3209, \\ Pietermaritzburg, South Africa
}

*Corresponding author: jayney480@yahoo.com

Abstract

Potato (Solanum tuberosum L.) is the third most important food crop in the world after wheat and rice while bacterial wilt is the second most important disease of potatoes after late blight. In high latitudes and high altitudes in the tropics, bacterial wilt is caused by race 3/biovar 2A (R3bv2A) (phylotype IIB, sequevar 1 ) while in the tropical lowlands, the disease is caused mainly by race 1 and biovar 2T. Control of bacterial wilt has proven to be very difficult. Breeding for resistance has been going on for long in many places such as the International Potato Center (CIP), University of Wisconsin, Brazilian Agricultural Research Corporation (Embrapa Hortaliças, Brazil), Uruguay and Peru. Classical breeding has achieved moderate unstable level of resistance/tolerance due to hostpathogen-environment interaction. In addition, hybridisation of the cultivated potato with the wild relatives have showed wild traits such as high glycoalkaloid content in addition to moderate levels of resistance to bacterial wilt. In recent years, genetic engineering for disease resistance has been employed such as the use of potent antimicrobial peptides and pattern recognition receptors. However, most of this work is in experimental stages. The purpose of this review is to document the progress made in breeding for resistance to bacterial wilt of potatoes. Though great strides have been made, there is still a long way to go before varieties with stable resistance coupled with good agronomic characteristic are released. There is light in the horizon though a bit far.

Keywords: Bacterial wilt resistance; Breeding; Potatoes.

\section{Introduction}

Bacterial wilt is the second most important potato disease in tropical and sub-tropical regions of the world after late blight (Champoiseau et al., 2010). Globally, the disease has been estimated to affect about 1.7 million hectares of potatoes in approximately 80 countries, with global damage estimates of over USD 950 million per annum (Champoiseau et al., 2009). In addition to potatoes, the disease also affects over 200 plant species from more than 50 families (Hayward, 1991). Bacterial wilt is widely distributed in tropical, subtropical, and warm temperate climates of the world, and it occurs in about 45 countries in the southern hemisphere (EPPO, 2004). Race 3/biovar 2A (R3bv2A) known as the potato or low temperature race causes bacterial wilt of potato in over $90 \%$ of cases worldwide in high latitudes and high altitudes in the tropics (Seal et al., 1999; Hayward, 2000; French, 1994; EPPO, 2004). In warm tropical lowlands, bacterial wilt is caused mainly by race 1 (biovars 1,3 and 4) (French, 1994; EPPO, 2004). Breeding for resistance to R3bv2A strains is supposed to be easier due to its relatively narrow host range and genetic homogeneity compared to lowland strains (race 1 and biovar 2T). When targeting the lowland strains, bacterial wilt resistance must be combined with heat tolerance for the humid tropics (Priou et al., 2001). Breeding for resistance to bacterial wilt has been going on for long in many places such as the International Potato Center (CIP), University of Wisconsin, Brazilian Agricultural Research Corporation (Embrapa Hortaliças, Brazil), Uruguay and Peru. Although wild relatives of potatoes have shown moderate resistance, crosses with cultivated potato produce varieties with poor agronomic traits.

The purpose of this review is to document the progress made in breeding for resistance to bacterial wilt of potatoes.

\section{The causal pathogen}

Bacterial wilt of potatoes is caused by the bacterium Ralstonia solanacearum (Yabuuchi et al., 1995) (formerly Pseudomonas solanacearum and Burkholderia solanacearum), which was described for the first time as Bacillus solanacearum by Smith in 1896 (EPPO, 2004). The bacterium is a soilborne vascular pathogen of worldwide distribution; it causes bacterial wilt in an unusually broad host range of plants (more than 200 species) from highly diverse botanical families including monocots and dicots 
(Hayward, 1964). Ralstonia solanacearum is considered a 'species complex' due to significant variation at different levels (physiological, serological, genetic characteristics and host range) within the group (Fegan and Prior, 2005). Ralstonia solanacearum is one of the world's most important phytopathogenic bacteria due to its lethality, persistence in the fields, wide host range, and broad geographic distribution (Elphinstone, 2005); it is present on all continents and many islands between the Tropics of Cancer and Capricorn (Denny, 2006). This wide geographic distribution, large host range and the exceptional capacity of this organism to adapt to many different environments is mirrored in the astonishing phenotypic and genetic diversity at the strain level. Traditionally, this pathogen has been subdivided into five races based on host range under field conditions. The bacterium has also been classified into biovars; biovars are based on their ability to produce acid from several disaccharides and sugar alcohols (Buddenhagen, 1986; Seal et al., 1999; Denny, 2006; Table 1). Biovars 3,4 , and 5 are the most versatile in terms of the range of carbon sources (Table 1). Later, a new group of $R$. solanacearum isolates from the Amazon basin was differentiated from the original biovar 2 using ribose and trehalose (Hayward, 1994). This new group is known as biovar 2-T ( $T$ for tropical) in recognition of its lowland origin or biovar N2 (new biovar 2) while the original biovar 2 strains are now referred as biovar 2A (A for Andean) in recognition of its highland origin (Denny, 2006). The biovars do not correlate with the races and only race 3 , the potato race, is equivalent to biovar $2 \mathrm{~A}$ (Amat et al., 1978) while race 5 is identical to biovar 5 (Hayward, 1983; Champoiseau et al., 2009). Race assignment to biovar 2-T strains is problematic because they exhibit a wider host range than do the archetypal biovar 2A (race 3) strains (Dennis, 2006; Table 2). Biovar $2 A$ has the least host range whereas biovar 3 has the widest (Table 2). Race 3 is thought to have evolved in the Andes Mountains and it appears to be well adapted to cooltemperate climates (Elphinstone, 1996; French, 1986; Hayward, 1991). Consequently, race 3 (Biovar 2A) is known as the potato or low temperature race and is found in high latitudes, and high altitudes in the tropics (Seal et al., 1999; Hayward, 2000). Race 3/biovar 2A (R3bv2A) causes bacterial wilt of potato in over $90 \%$ of cases worldwide because potato is a cool season crop (French, 1994; EPPO, 2004). Potato is the common host for R3bv2A, but when there is high pathogen inoculum concentration in the soil, and high temperature, it can also infect tomatoes or a few other crops when they are grown in rotation (Buddenhagen, 1986; French, 1994; EPPO, 2004). The R3bv2A probably originated in the Andes and was apparently disseminated worldwide on potato tubers. It now occurs in tropical highlands and in subtropical and warm-temperate areas throughout the world, except in North America (Buddenhagen, 1986). It is also widespread in the higher latitudes as far as southern Sweden and southern Argentina (Champoiseau et al., 2009). The R3bv2A is the main cause of bacterial wilt of potatoes in the Kenyan highlands (Smith et al., 1995). With the expansion of potato production into warmer subtropical and tropical lands, cases of lowland bacterial wilt caused by race 1(biovars 1, 3 and 4) have occurred (French, 1994; EPPO, 2004).

The old classification system of the pathogen into races and biovars is unsatisfactory because it is not predictive and some groups (e.g. race 1) contain very large variation. In addition, race determination is not possible because $R$. solanacearum strains do not have race-cultivar specificity on plant hosts and, with the exception of R3b2A, the old "races" do not have phylogenetic unity (Fegan and Prior, 2005; Champoiseau et al., 2010). A recent phylogenetic classification scheme based on DNA sequence analysis divided the species complex into four phylotypes that broadly reflect the ancestral relationships and geographical origins of the strains (Table 3). Phylotype I strains originated in Asia, phylotype II strains in the Americas, phylotype III strains in Africa, and phylotype IV strains in Indonesia. Phylotypes are further subdivided into sequevars based on the sequence of the endoglucanase (egl) gene (Prior and Fegan, 2005). Currently there are a total of 53 known sequevars within the four phylotypes. Ralstonia solanacearum race 3 biovar $2 \mathrm{~A}$ (R3b2A) belongs to phylotype II. Phylotype II has two sub clusters: These two sub-clusters have been called phylotype II- bhr (phylotype IIA) and phylotype II-nhr (phylotype IIB) for broad and narrow host range, respectively. The former group (phylotype II-bhr) is made of $R$. solanacearum strains which are pathogenic to many solanaceous hosts including tomato and Musa spp. Phylotype II-nhr (phylotype IIB) can be resolved into $R$. solanacearum race 3 strains pathogenic to potatoes grown in the highlands and $R$. solanacearum race 2 strains causing moko disease in bananas (Fegan and Prior, 2005). Ralstonia solanacearum race 3 biovar 2A (R3b2A) belongs to phylotype IIB, sequevars 1 and 2; strains belonging to the phylotype II-nhr sequevar 1 (phylotype IIB, sequevar 1) are the main ones responsible for bacterial wilt of potato in cold and temperate regions (Denny 2006; Siri et al., 2011). UY031 is a highly aggressive strain that belongs to this sequevar and was isolated from potato tubers in Uruguay in 2003 (Siri and Pianzzola 2011; Siri et al., 2009). Phylotypes are not related with host preference as strains from all phylotypes are able to cause disease on potato, tomato, pepper, and eggplant (Cellier and Prior, 2010; Lebeau et al., 2011).

\section{The disease}

Bacterial wilt of potato, often called brown rot, can be caused by strains of race 1 (biovars $1,3,4$ ) and biovar $2 T$ in warm climates, and by biovar 2A (race 3 ) strains in both warm and cool climates (Denny, 2006). Consequently, bacterial wilt is a limiting factor in potato production in both lowland and highland tropics (French, 1994; Lemaga et al., 2005). In potatoes, the bacterium is tuber borne, and is primarily disseminated through infected seed tubers (Champoiseau et al., 2009). Potato seed tubers carry the bacterium in the vascular tissue, lenticels, and on the surface (Kelman, 1953; Sunaina et al., 1989). The other source of inoculum is the infested soil; the bacteria is native in many tropical soils (Martin and French, 1985). Bacterial wilt is further spread through infected run-off water or soil adhering to tools and shoes (Martin and French, 1985; Pradhanang, 1999). Under field conditions, plant infection usually occurs through the root system, especially through wounds (Kelman, 1953). The pathogen can also enter through stem wounds or stomata (EPPO, 2004). Wounds can occur due to cultivation activities, natural growth of secondary roots, attack by nematodes or other pests (Martin 
and French, 1985; Shekhawat and Chakrabarti, 1993). Once introduced, the pathogen survives at soil depths of $1 \mathrm{~m}$ or more, where microbial competition is low, or as slimy masses in the upper soil layers (Kinyua et al., 1998). The pathogen can survive in soil (mostly on plant debris) and in the rooting system and rhizosphere of many hosts (weeds, other host crops, potato volunteers). Survival of the pathogen in the soil is reduced by extreme cold and the presence of antagonistic microorganisms while volunteer host plants enable bacterial survival across seasons (Martin and French, 1985; Hayward, 1991; Milling et al., 2009). Survival depends also on the race involved; race1 usually persists for many years in the soil because of its numerous hosts, while R3bv2A tends to persist for a few years due to limited hosts (Martin and French, 1985; Champoiseau et al., 2009). The aggressiveness of the pathogen is affected mainly by temperature and moisture; high temperature and high soil moisture promote survival, reproduction, infectivity, and spread of the bacterium, and hence disease development (Harris, 1976; Martin and French, 1985). Temperature is the most important factor affecting the host-pathogen interaction as well as survival in soils. In general, increase in ambient temperature to between 30 and $35^{\circ} \mathrm{C}$ increases the incidence and rate of onset of bacterial wilt on hosts such as tomato, for many but not all strains of the pathogen (Hayward, 1991). Survival of the pathogen is greatest in wet but well-drained soils (Kinyua et al., 1998; Champoiseau et al., 2009) whereas it is adversely affected by soil desiccation and by flooding (Buddenhagen and Kelman, 1964). It has also been reported that bacterial wilt incidence is increased by low soil $\mathrm{pH}$ and low soil fertility (Lemaga et al., 2001; Lemaga et al., 2005; Messiha, 2006).

Foliage symptoms of the disease include wilting caused by extensive multiplication of the bacterium in the xylem vessels, which hinders water flow in the plant. In wellestablished infections, cross-sections of stems may reveal brown discoloration of infected tissues (EPPO, 2004) and a white, slimy mass of bacteria may exude from the vascular bundles of the cross-sections (Martin and French, 1985; Hayward, 1991; EPPO, 2004). In addition, the bacterium can colonize asymptomatically several weeds that act as pathogen reservoirs (Genin and Denny, 2012), and survive in waterways and soil for long periods (Caruso et al., 2005; Elphinstone, 2005). These facts, together with lack of resistant commercial varieties in any of its hosts (Hong et al., 2005), render the control of bacterial wilt very challenging.

\section{Management of bacterial wilt of potatoes}

Control of $R$. solanacearum is difficult because it is a soil borne pathogen, has wide host range, long survival in the soil, and has wide biological variation (Martin and French, 1985). No single control method has been found to be $100 \%$ effective although in locations where the pathogen is established, some level of bacterial wilt control has been possible through use of a combination of diverse methods (EPPO, 2004; Champoiseau et al., 2010). These methods include phytosanitation and cultural practices, chemical control, biological control, and host resistance (Martin and French, 1985; Champoiseau et al., 2010). Phytosanitation and cultural practices are the most widely used practices for controlling bacterial wilt in the field (Martin and French,
1985; Champoiseau et al., 2010). These practices can be effective in regions where bacterial wilt is endemic, or in locations where it is present but not yet established (French, 1994; Champoiseau et al., 2010). Phytosanitation practices include planting disease-free tuber seeds, and quarantine measures, while cultural practices include crop rotation, intercropping, delayed planting, soil amendments, positive selection, and negative selection (Kinyua et al., 2001; EPPO, 2004; Champoiseau et al., 2010).

\section{Breeding for resistance}

Use of resistant potato varieties to control bacterial wilt is probably the cheapest and most practical means because chemicals are generally ineffective, phytosanitation and cultural measures are difficult to apply, and biological control agents are not commercially available (Martin and French, 1985; Champoiseau et al., 2010). Unfortunately for most crops susceptible to bacterial wilt, there are almost no sources of high level, gene-for-gene type of resistance encoded by single dominant genes. Instead, available sources of resistance are usually polygenic and it has been difficult or impossible to transfer all the identified quantitative trait loci (QTL) into desirable cultivars due to their number or linkage to undesirable traits. Loci providing quantitative resistance to bacterial wilt have been identified in tomato (Mangin et al., 1999; Wang et al., 2000; Carmeille et al., 2006), tobacco (Qian et al., 2013), and eggplant (Lebeau et al., 2013); however, there are no commercial varieties resistant against $R$. solanacearum available (Huet, 2014). The only exception is groundnut where dominant resistance genes were identified long ago and introduced into all four botanical types of Arachis hypogaea to produce cultivars with high-level resistance (Denny, 2006).

In potatoes, the best that normal breeding has achieved is moderate level of resistance/tolerance (i.e. satisfactory yield despite infection) to bacterial wilt on a regional level when conditions are not excessively hot or wet; some potato cultivars are less susceptible to bacterial wilt at least in some regions (Champoiseau et al., 2010). Previously/ screening of Solanum tuberosum, clones showed resistance that was not good enough to be used in breeding programmes (Jaworski et al., 1980; Michel and Mew, 1998). Wild potato relatives have been used to generate resistant potato cultivars (Sequeira and Rowe, 1969; Carputo et al., 1997; Narancio et al., 2013). Bacterial wilt resistance has been reported in Solanum stenotomum (Fock et al., 2001), S. chacoense (Chen et al., 2013), S. phureja (Sequeira and Rowe, 1969; French and De Lindo, 1982; Fock et al., 2000), and S. commersonii Dun (Laferriere et al., 1999; Kim-Lee et al., 2005; Carputo et al., 2009; González et al., 2013). However, efforts to transfer bacterial wilt resistance from wild potato relatives have been disappointing; sexual hybrids of potato with resistant genotypes of S.chacoense, S. sparsipillum, S. raphanifolium, S. microdontum and S. multidissectum showed wild traits such as high glycoalkaloid content in addition to moderate levels of resistance to bacterial wilt (French et al., 1997). Other sources of resistance which have been evaluated are S. stenotomum $L$ (cultivated), and S. commersonii Dun, which is wild (Laferriere et al., 1999; Fock et al., 2000; 2001; Carputo et al., 2009). They too showed moderate resistance and their hybrids harbour latent infection (Laferriere et al., 
Table 1. Differentiation of Ralstonia solanacearum into biovars.

\begin{tabular}{lllllll}
\hline \multirow{2}{*}{ iochemical Test } & Biovars & & & & & \\
\cline { 2 - 7 } & & 1 & $2 \mathrm{~A}$ & 3 & 4 & 5 \\
\hline & Mannitol & - & - & + & + & + \\
\multirow{5}{*}{ Oxidation of } & Sorbitol & - & - & + & + & - \\
\hline \multirow{3}{*}{ Utilization of } & Dulcitol & - & - & + & + & - \\
\hline
\end{tabular}

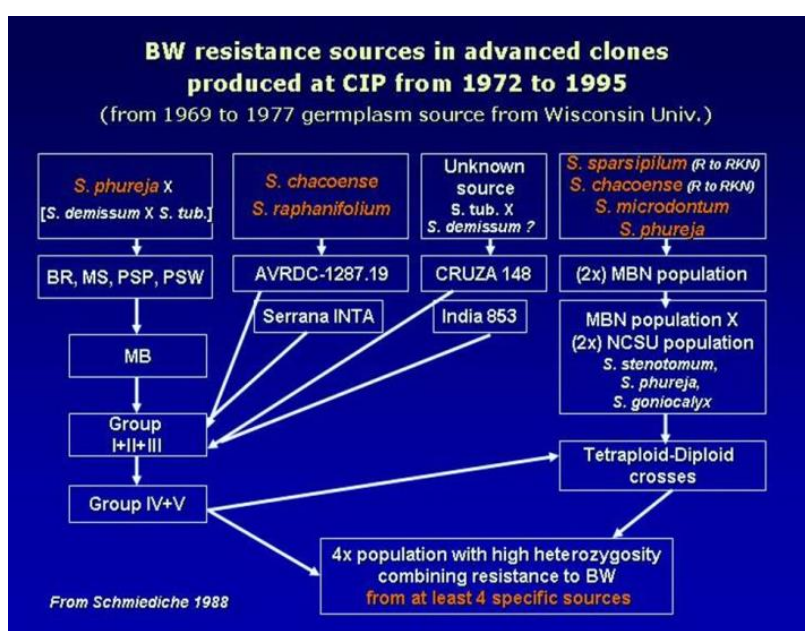

Fig 1.Sources of resistance to bacterial wilt and their utilization at CIP. Schmiediche, 1988

Table 2. Equivalence between biovars and races of Ralstonia solanacearum.

\begin{tabular}{llll}
\hline Race & Biovars & Hosts & Location \\
\hline 1 & $1,3,4$ & All Solanaceous crops + many other hosts & $\begin{array}{l}\text { Lowland tropics (Asia, Americas } \\
\text { and Australia) } \\
\text { American and Asian tropics } \\
\text { (Caribbean, Brazil, Philippines) } \\
\text { Cool climate worldwide }\end{array}$ \\
3 & 1,3 & Bananas and other Musa species & Asia \\
4 & $2 \mathrm{~A}$ & Potato and tomatoes & China \\
5 & 3,4 & Ginger & Amazon basin \\
\hline
\end{tabular}

Source: EPPO, 2004.

Table 3. Equivalences among phylotypes, biovars and races of $R$. solanacearum

\begin{tabular}{|c|c|c|c|c|c|c|c|c|c|c|c|c|c|}
\hline \multirow{2}{*}{$\begin{array}{l}\text { Species } \\
\text { Phylotype }\end{array}$} & \multicolumn{13}{|c|}{ Ralstonia solanacearum } \\
\hline & I & & & II & & & III & & IV & & & & \\
\hline Origin & Asia & & & $\mathrm{Am}$ & & & Afric & & Ind & esia & & & \\
\hline Biovars & 3 & 4 & 5 & $2 T$ & 1 & $2 \mathrm{~A}$ & $2 T$ & 1 & $2 T$ & 1 & 2 & $\mathrm{R}$ & B \\
\hline Races & 1 & 4 & 5 & 1 & 2 & 3 & & & & & & & \\
\hline
\end{tabular}

$\mathrm{R}=$ Ralstonia syzygii; $\mathrm{B}=$ Pseudomonas celebense. Source: Prior and Fegan, 2005.

1999; Fock et al., 2000; 2001). Unlike these wild species, Solanum phureja (cultivated Tuberosa) is phylogenetically close to Solanum tuberosum and displays resistant traits which are dominant and readily transmitted to progeny. Some clones of S. phureja with high degree of resistance to bacterial wilt have been used for crossing with commercial cultivars of S. tuberosum (French et al., 1998; Sequeira and Rowe, 1969). Resistance to bacterial wilt available now in Solanum tuberosum originated mainly from the cultivated diploid, Solanum phureja (Martin and French, 1985). However, this resistance has been found to be strain-specific and sensitive to high temperatures (Sequeira and Rowe, 1969; Sequeira, 1979; Ciampi and Sequeira, 1980; French and Lindo, 1982). High temperature is the most important factor causing the breakdown of this resistance (French and Lindo, 1982). This resistance is seldom expressed as immunity because it is overcome by factors that favour the disease development i.e. high temperature, high soil moisture, low soil $\mathrm{pH}$, low soil fertility, and damage to the plant root system (Martin and French, 1985; Low, 1997). In recent times, the wild $S$. commersonii Dun has emerged as a source of high resistance against bacterial wilt. This wild species exhibits a high genetic diversity (Pianzzola et al. 2005; Siri et al. 2009) and possess many desirable traits such 
as tolerance to low temperatures and resistance to several pathogens, including $R$. solanacearum (Carputo et al., 2009; Galván et al., 2006; Gonzalez et al., 2013; Kim-Lee et al. 2005; Laferriere et al. 1999; Narancio et al. 2013; Siri et al. 2009). Due to these valuable traits, S. commersonii is being used as the main genetic resource for the potato breeding program at the National Institute of Agricultural Research of Uruguay (INIA) which focuses on the development of improved potato varieties with high levels of field resistance to bacterial wilt (Galván et al., 2006; Gonzalez et al., 2013; Narancio et al., 2013). In Brazil, breeding for bacterial wilt resistance was started at Embrapa Hortaliças in 1987 by means of a cooperative project with the International Potato Center (CIP), Lima, Peru. After 30 years of non-stop germplasm breeding activities, two clones, MB-03 and MB9846-01 (both derived from S. phureja), stood out for their highly stable resistance to bacterial wilt (Silveira et al., 2007). Although the two clones are not commercially appealing in Brazil, they are a precious source of resistance and have been widely used in Embrapa's breeding program in crosses with genitors that favour tuber appearance and quality (Lopez, 2018).

At the University of Wisconsin, systematic breeding for resistance to bacterial wilt started in 1967 (Schmiediche, 1985a). Rowe and Sequeira (1972) began this program by intercrossing a few resistant diploid clones of $S$. phureja, which had been found in the Central Colombian Collection (CCC), with S. tuberosum ssp. tuberosum germplasm. In 1979, the Wisconsin breeding program sent 369 clones representing 10 families to the International Potato Center (CIP), Peru; they also sent similar set of materials to 20 countries around the world (Schmiediche, 1985a).

\section{History of breeding for bacterial wilt resistance at CIP}

Bacterial wilt research at CIP began just after its establishment in 1971; the University of Wisconsin entered into a research contract with CIP and began to send more materials. At CIP, the materials were identified by codes such as BR, MS, PSP, or PSW. The CIP's breeding program for resistance to bacterial wilt had the Wisconsin germplasm as the only source of resistance (the CCC clones of S. phureja); bacterial wilt resistant hybrids produced in the early years at CIP were coded MB (Schmiediche, 1985a). For a long time, breeding for bacterial wilt resistance at CIP involved two clones of S. Phureja as the sources of resistance. Due to instability of this resistance, there was need to widen the source base by including other species (Schmiediche, 1988). In addition, the resistance of $S$. phureja was genetically very narrowly based and S. phureja-derived material had shown limitations with regard to earliness and heat adaptation (Schmiediche, 1996). A new source of specific resistance to bacterial wilt was introduced from the Asian Vegetable Research and Development Center (AVRDC) in Taiwan which developed AVRDC 1287.19. This clone had the wild species $S$. chacoense and S. raphanifolium in its pedigree; both species are known to have resistance to bacterial wilt. Later, the AVRDC clone was rejected because its progenies showed wild traits such as high glycoalkaloid content in addition to moderate levels of resistance to bacterial wilt (French et al., 1997; Schmiediche, 1996).

Breeding efforts continued at CIP in screening wild species of Solanum in hope of finding general resistance that would not be as vulnerable to high temperatures as the $S$. phureja sources had proved to be (French and Sequeira, 1988). In the 1990s, advanced tetraploid potato clones were obtained from a 14-yr programme of breeding for bacterial wilt resistance at CIP. These clones were produced after various crosses with (i) clones derived from Colombian S. phureja genotypes produced at the University of Wisconsin's breeding programme initiated in the 1970 s by Sequeira and Rowe (1969), (ii) clone AVRDC-1287.19 derived from $S$. chacoense and S. raphanifolium, (iii) progenitors derived from wild species $S$. chacoense and $\mathrm{S}$. sparsipilum to combine other sources of bacterial wilt resistance, (iv) $S$. tuberosum subsp. tuberosum genotypes that carried earliness, adaptation to heat, resistance to late blight and root-knot nematode, and immunity to potato virus $X$ and potato virus $\mathrm{Y}$, and $(\mathrm{v})$ a population of diploid cultivated species S. stenotomum, S. phureja and S. goniocalyx from a breeding programme at North Carolina State University for high yield and good agronomic characteristics (Schmiediche and Martin, 1986; Schmiediche, 1988; Anguiz and Mendoza, 1997). From these crosses, a highly heterozygous tetraploid population combining at least four sources of specific resistance to bacterial wilt was generated (Figure 1). These tetraploid materials, with broad genetic base, were far superior in bacterial wilt resistance than the traditional $S$. phureja-based materials. However, like S. phureja-based resistance, these tetraploid clones did not have complete resistance, resistance was affected by high temperature and they also harboured latent infection (Schmiediche, 1996).

\section{Genetic transformation for improved bacterial wilt} resistance in potatoes

Resistance genes have been identified in wild potato species; however, introduction of these through classical breeding has achieved only partial resistance in addition to poor agronomic performance (Boschi et al., 2017). Complex interspecific crossing barriers that have hampered classical breeding have been overcome through different strategies for ploidy manipulation (Fock et al., 2000; 2001; Wanatabe et al., 1992). Consequently, hybrids of $S$. commersonii $x S$. tuberosum with partial resistance to bacterial wilt were obtained (Kim-Lee et al., 2005; Carputo et al., 2009; Guidot et al., 2009; González et al., 2013; Narancio et al., 2013; Cruz et al., 2014).

In recent years, genetic engineering for disease resistance particularly the use of many potent antimicrobial peptides from plant resources such as enzyme inhibitors, lectins, pathogenesis-related proteins and thionins, has been demonstrated (Bohlmann, 1994). Control of bacterial diseases has been made possible through genetic engineering using genes found in fungi, insects, animals and other plants. Antimicrobial proteins (AMP), peptides and lysozymes that naturally occur in insects (Jaynes et al., 1987), plants (Broekaert et al., 1997), animals (Vunnam et al., 1997) and humans (Nakajima et al., 1997) are now a potential source of plant resistance. For example, Antimicrobial Peptide 1 (AP1) is a plant endogenous antimicrobial protein isolated from bacterial wilt resistant potato clone MS42.3. Transgenic potato expressing AP1 genes have shown increased resistance to bacterial wilt (Liang and He, 2002). Cecropins, attacins and lysozymes possess a broad spectrum of anti-microbial activity against 
both Gram positive and Gram negative bacteria (Gupta, 2016). Cecropins are probably the best-known antibacterial peptides of insect origin (Patil et al., 2012). Several analogues of this native peptide have been artificially synthesized and a few of them like SB-37 and Shiva-1 were found to be more effective than the native protein molecule. Genes encoding SB-37 and Shiva-1 have since been introduced into potato. Transgenic plants when inoculated with virulent $R$. solanacearum showed delayed symptom expression and reduced disease severity and lower rate of plant mortality (Montanelli et al., 1995). The Biotechnology Research Center of the Chinese Academy of Agricultural Sciences (CAAS) has introduced a synthetic gene for an antibacterial peptide into a major potato cultivar extensively planted in China and obtained transgenic potato lines with improved resistance to several diseases including bacterial wilt (Jia et al., 1998; 1993). These anti-bacterial peptide genes have been supplied to several research institutes for bacterial wilt resistance improvement in potato, peanut, and tomato and resistance to other diseases including Chinese cabbage soft rot (Boshou, 2005).

Research has showed that interfamily transfer of pattern recognition receptors (PRR) is an interesting strategy for engineering broad-spectrum disease resistance that may be durable (Zipfel and Oldroyd, 2017). The elongation factor-Tu (EF-Tu) receptor (EFR) from Arabidopsis thaliana (AtEFR) is a PRR that recognizes the bacterial PAMP EF-Tu (Kunze, 2004; Zipfel et al., 2006). Researchers evaluated the effect of AtEFR gene expression in a commercial potato line (INIA Iporá) and in an interspecific breeding line (09509.6), into which quantitative resistance to bacterial wilt from the wild relative $S$. commersonii has been introgressed (Boschi et al., 2017). They found that both INIA Iporá and 09509.6 potato lines expressing AtEFR showed greater resistance to $R$. solanacearum, with no detectable bacteria in tubers. In addition, greater survival rates and reduced disease symptoms were observed in 09509.6-AtEFR compared with INIA Iporá-EFR lines. For both genetic backgrounds the expression of the AtEFR gene controlled bacterial cell population, thus preventing the conversion to the pathogenic phenotype.

In order to guarantee success of long-term breeding programs, resistance to latent infection by $R$. solanacearum should be sought because latently infected seed potatoes are a common source of inoculum (Priou et al., 1999). Towards this end, researchers have developed a method for high-throughput evaluation of $R$. solanacearum colonization in potato plants using a Luminescent Ralstonia solanacearum Reporter Strain (Cruz et al., 2014). This nondestructive method allows for easy tracking and quantification of bacterial colonization and latency in plants. In developing this method, the highly aggressive $R$. solanacearum strain UY031 (race 3, biovar 2A/phylotype IIB, sequevar 1) was genetically modified to constitutively generate light from a synthetic I $\mathrm{x} C D A B E$ operon stably inserted in its chromosome. Colonization of this reporter strain on different potato accessions was followed using life imaging. Previously, $R$. solanacearum YN5 was transformed with a plasmid carrying the luxCDABE operon to qualitatively study pathogen colonization in susceptible and resistant tomato (Hikichi et al. 1999).

In addition identification of new resistance sources could be accelerated by exploiting $R$. solanacearum effectors through an effectoromics approach (Vleeshouwers and Oliver, 2014), as well as through the molecular characterization of their virulence and avirulence functions. Once identified, monogenic over polygenic resistances should be prioritized to facilitate their transfer into crops and provide a higher level of resistance more likely to favour the eradication of $R$. solanacearum (Huet, 2014). After identifying new resistance sources, to increase the chance of success in achieving durable resistance to bacterial wilt, $R$-gene stacking in fields should be applied (Dangl et al., 2013).

\section{Conclusion}

Classical breeding for bacterial wilt resistance has resulted in unstable resistance due to host-pathogen-environment interaction; a more realistic approach would be to seek for sources of resistance adapted only to a given ecosystem or to use a "cocktail" of diverse $R$. solanacearum strains during screening. The diversity of the pathogen strains may explain the variability of resistance in different locations. In recent years, genetic engineering for bacterial wilt resistance has been tried; however, few if any transgenic potatoes has been commercialized. It should be noted that to some extent, resistance to bacterial wilt in many crops is negatively correlated with yield and quality; this may affect acceptance of resistant varieties. Consequently, breeding efforts should seek to integrate resistance to bacterial wilt with desirable agronomic traits as well as resistances to other biotic and abiotic constraints so as to develop cultivars that are acceptable.

\section{References}

Amat Z, Albornoz A, Hevesi M, Stefanova M (1978) Pseudomonas solanacearum detected in a naturally infested soil containing a new wild host. Proceedings of the Fourth International Conference on Plant Pathogenic Bacteria, Angers, pp. 869-873.

Anguiz RJ, Mendoza HA (1997) General and specific combining abilities for resistance to bacterial wilt (Pseudomonas solanacearum E.F. Smith) in PVX and PVY immune autotetraploid potatoes. Fitopatologia 32: 71-80.

Bohlmann $\mathrm{H}$ (1994) The role of thionins in plant protection. Crit Rev Plant Sci. 13:1-6.

Boschi F, Schvartzman C, Murchio S, Ferreira V, Siri MI, Galván GA, Smoker M, Stransfeld L, Zipfel C, Vilaró FL, Dalla-Rizza M (2017) Enhanced bacterial wilt resistance in potato through expression of Arabidopsis EFR and introgression of quantitative resistance from Solanum commersonii. Frontiers in Plant Science. 8:1-11.

Boshou L(2005) A broad review and perspective on breeding for resistance to bacterial wilt. p. 225-238. In: Allen C, Prior P, Hayward AC (eds) Bacterial Wilt Disease and the Ralstonia solanacearum Species Complex. American Phytopathological Society, St. Paul, MN, USA.

Broekaert WF, Cammue BPA, De Bolle MFC, Thevissen K, De Samplax GW, Osborn RW, Nielson K (1997) Antimicrobial peptides from plants. Crit Rev Plant Sci. 16:297-323

Buddenhagen IW (1986) Bacterial wilt revisited. p. 126-143. In: Persley GJ (ed) Bacterial wilt disease in Asia and the South Pacific. Proceedings of an International Workshop on Bacterial wilt, 8-10 October 1985, PCARRD, Los Banos, 
Philippines. Australian Centre for International Agricultural Research, Canberra, Australia.

Buddenhagen I, Kelman A (1964) Biological and physiological aspects of bacterial wilt caused by $P$. solanacearum. Annual Review of Plant Pathology. 2: 203-230.

Carmeille A, Caranta C, Dintinger J, Prior P, Luisetti J, Besse P (2006) Identification of QTLs for Ralstonia solanacearum race 3-phylotype II resistance in tomato. Theor Appl Gen. 113:110-121.

Carputo D, Aversano R, Barone A, Matteo A, Lorizzo M, Sigillo L, Zoina A, Frusciante L (2009) Resistance to Ralstonia solancearum of sexual hybrids between Solanum commersonii and Solanum tuberosum. Ame J Pot Res. 86: 196-202.

Carputo DCT, Speggiorin M, Zoina A, Frusciante L (1997) Resistance to blackleg and tuber soft rot in sexual and somatic interspecific hybrids with different genetic background. American Potato Journal. 74: 161-172.

Caruso P, Palomo JL, Bertolini E, Álvarez B, López MM, Biosca EG (2005) Seasonal variation of Ralstonia solanacearum biovar 2 populations in a Spanish river: Recovery of stressed cells at low temperatures. Appl Environ Microbiol. 71:140-148.

Cellier G, Prior P (2010) Deciphering phenotypic diversity of Ralstonia solanacearum strains pathogenic to potato. Phytopathology 100: 1250-1261.

Champoiseau PG, Jones JB, Allen C (2009) Ralstonia solanacearum race 3 biovar 2 causes tropical losses and temperate anxieties [Online]. American Phytopathological Society. Madison, WI, USA. DOI: 10.1094/PHP-2009-031301-RV

Champoiseau PG, Jones JB, Momol TM, Pingsheng J, Allen C, Norman DJ, Harmon C, Miller SA, Schubert T, Bell D, Floyd JP, Kaplan D, Bulluck R, Smith K, Caldwell K (2010) Ralstonia solanacearum Race 3 biovar 2 causing brown rot of potato, bacterial wilt of tomato and southern wilt of geranium [Online]. Available at http://plantpath.ifas.ufl.edu/rsol/NRI Project/Projectsum mary.html (Accessed 25 June 2018). American Phytopathological Society. Madison, WI, USA.

Chen L, Guo X, Xie C, He L, Cai X, Tian L, Song B, Liu J (2013) Nuclear and cytoplasmic genome components of Solanum tuberosum $X$ S. chacoense somatic hybrids and three SSR alleles related to bacterial wilt resistance. Theor Appl Gen. 126: 1861-1872.

Ciampi L, Sequeira L (1980) Influence of temperature on virulence of race 3 strains of Pseudomonas solanacearum. American Potato Journal. 57: 307-317.

Cruz APZ, Ferreira V, Pianzzola MJ, Siri MI, Coll NS, Valls M (2014) A novel, sensitive method to evaluate potato germplasm for bacterial wilt resistance using a luminescent Ralstonia solanacearum reporter strain. Mol Plant Microb Interact. 27: 277-285.

Dangl JL, Horvath DM, Staskawicz BJ (2013) Pivoting the plant immune system from dissection to deployment. Science. 341: 746-751.

Denny TP (2006) Plant pathogenic Ralstonia species. p. 573644. In: Gnanamanickam SS (ed) Plant-Associated Bacteria. Springer Publishing, Dordrecht, The Netherlands.

Elphinstone JG (1996) Survival and possibilities for extinction of Pseudomonas solanacearum (Smith) Smith in cool climates. Potato Research. 39: 403-410.
Elphinstone JG (2005) The current bacterial wilt situation: A global view. p. 9-28. In: Allen C, Prior P, Hayward AC (eds) Bacterial Wilt Disease and the Ralstonia solanacearum Species Complex. American Phytopathological Society, St. Paul, MN, USA.

EPPO (2004) Ralstonia solanacearum. European and Mediterranean Plant Protection Organization Bulletin. 34: 173-178.

Fegan M, Prior P (2005) How complex is the "Ralstonia solanacearum species complex"? p. 449-461. In C. Allen, P. Prior, and A. C. Hayward (ed.) Bacterial wilt disease and the Ralstonia solanacearum species complex. American Phytopathological Society, St. Paul, MN, USA.

Fock I, Collonnier C, Purwito A, Luisetti J, Souvannavong V, Vedel F, Servaes A, Ambroise A, Kodja H, Ducreux G, Sihachakr D (2000) Resistance to bacterial wilt in somatic hybrids between Solanum tuberosum and Solanum phureja. Plant Science 160. 165-176.

Fock I, Collonnier C, Luisetti J, Purwito A, Souvannavong V, Vedel F, Servaes A, Ambroise A, Kodja H, Ducreux G, Sihachakr D (2001) Use of Solanum stenotomum for introduction of resistance to bacterial wilt in somatic hybrids of potato. Plant Physiology and Biochemistry. 3: 899-908.

French ER (1986) Interaction between strains of Pseudomonas solanacearum, its hosts and the environment. P. 99-104. In: Persley GJ (ed) Bacterial Wilt Disease in Asia and the South Pacific. ACIAR Proceedings No. 13. Canberra: Australian Centre for International Agricultural Research, Canberra, Australia.

French ER (1994) Strategies for integrated control of bacterial wilt of potatoes.p. 98-113. In: Hayward AC, Hartman GL (eds) Bacterial wilt: The disease and its causative agent, Pseudomonas solanacearum. CAB International, UK.

French ER, Lindo LD (1982) Resistance to Pseudomonas solanacearum in potato: Specificity and temperature sensitivity. Phytopathology. 72: 1408-1412.

French ER, Anguiz R, Aley P (1997) The usefulness of potato resistance to Ralstonia solanacearum for the integrated control of bacterial wilt. In: Prior PH, Allen C, Elphinstone J (eds.) Bacterial wilt disease: Molecular and ecological aspects. Report of the Second International Wilt Symposium, 22-27 June 1997, Gosier, Guadeloupe, France (pp. 381-385). Springer-Verlag, Berlin, Germany.

French ER, Sequeira L (1988) Additional sources of resistance to bacterial wilt. p. 28-30. Bacterial diseases of the potato. In: Report of the Planning Conference on Bacterial Diseases of the Potato 1987. CIP. Lima, Peru. 1988.

Galván G, Fraguas F, Quirici L, Santos C, Silvera E, Siri M, Villanueva $P$, Raudiviniche L, González M, Torres D, Castillo A, Dalla Rizza M, Vilaró F, Gepp V, Ferreira F, Pianzzola MJ (2006) Solanum commersonii: Una especie con gran potencial para el mejoramiento genético de papa por resistencia a Ralstonia solanacearum. Pages 87-102 In: Avances de investigación en recursos genéticos en el cono sur I. I. Procisur, ed. Procisur, Montevideo, Uruguay.

Genin S, Denny TP (2012) Pathogenomics of the Ralstonia solanacearum species complex. Annu Rev Phytopath. 50:67-89.

González M, Galván G, Siri MI, Borges A, Vilaró F (2013) Resistencia a la marchitez bacteriana de la papa en Solanum commersonii. Agrociencia Urug. 7: 45-54. 
Guidot A, Elbaz M, Carrère $S$, Siri MI, Pianzzola MJ, Prior $P$, Boucher $P$ (2009) Specific genes from the potato brown rot strains of Ralstonia solanacearum and their potential use for strain detection. Phytopathology. 99: 1105-1112.

Gupta J (2016) Genetic engineering of potato for disease and pest resistance: A review. Imperial Journal of Interdisciplinary Research 2:248-253.

Hayward AC (1983) Pseudomonas solanacearum: Bacterial wilt and moko disease. p. 129-135. In: Fahy PC, Persley GJ (eds) Plant bacterial diseases. Academic Press, Sydney, Australia

Hayward, A. C. (1964). Characteristics of $P$. solanacearum. Journal of Applied Bacteriology 27: 265-265.

Hayward AC (1991) Biology and epidemiology of bacterial wilt caused by Pseudomonas solanacearum. Annual Review of Phytopathology. 29: 65-87.

Hayward AC (1994) Systematics and phylogeny of Pseudomonas solanacearum and related bacteria. P. 123135. In: Hayward AC, Hartman GL (eds) Bacterial Wilt: The Disease and its Causative Agent, Pseudomonas solanacearum. Wallingford, UK: CAB International.

Hikichi Y, Nakazawa-Nasu Y, Kitanosono S, Suzuki K, Okuno T (1999) The behavior of lux-marked Ralstonia solanacearum in grafted tomato cultivars resistant or susceptible to bacterial wilt. Ann Phytopath Soc Jpn. 65:597-603.

Hong J, Ji P, Momol MT, Jones JB, Olson SM, Pradhanang P, Guven K (2005) Ralstonia solanacearum detection in tomato irrigation ponds and weeds. Pages 309-311 In: Proceedings of the First International Symposium on Tomato Disease, International Society for Horticultural Science, Orlando, FL, U.S.A.

Huet G (2014) Breeding for resistances to Ralstonia solanacearum. Frontiers in Plant Science. 5:1-5.

Janse J, Beld D, van Den H (2004) Introduction to Europe of Ralstonia solanacearum biovar2, race3 in Pelargonium zonale cuttings. J Plant Pathol. 86: 147-155.

Jaworski CA, Webb RE, Goth RW, Phatak SC (1980) Relative resistance of potato cultivars to bacterial wilt. Am Pot J. 57:159-164

Jaynes JM, Xanthopoulos KG, Deste'fano BL, Dodds JH (1987) Increasing bacterial disease resistance in plants utilizing antibacterialgenes from insects. Bioassays. 6:263-270.

Jia SR Xie Y, Tang T, Feng LX, Cao DS, Zhao YL, Yuan J, Bai YY, Jiang CX, Jaynes JM, Dodds JD (1993) Genetic engineering of Chinese potato cultivars by introducing antibacterial polypeptide gene. p. 208-212. In: Chen ZL (ed) Biotechnology in Agriculture. Proceedings of the first AsiaPacific Conference on Agricultural Biotechnology, Beijing, China, 20-24 August 1992.

Jia SR, Qu XM, Feng LX, Tang T, Tang YX, Liu K, Zheng P, Zhao YL, Bai YY, Cai MY (1998) Development of potato clones with enhanced resistance to bacterial wilt by introducing antibacterial peptide gene. Sci Ag Sinica. 31:13-18.

Kelman A (1953) Bacterial wilt caused by Pseudomonas solanacearum. A literature review and bibliography. Springer-Verlag, Berlin, Germany.

Kim-Lee H, Moon JS, Hong YJ, Kim MS, Cho HM (2005) Bacterial wilt resistance in the progenies of the fusion hybrids between haploid of potato and Solanum commersonii. Am J Potato Res. 82: 129-137.

Martin C, French ER (1985) Bacterial wilt of potatoes caused by Pseudomonas solanacearum. Technical Information
Kinyua ZM, Smith JJ, Lung'aho C, Olanya M, Priou S (2001) On-farm success and challenges of producing bacterial wilt free tubers in seed plots in Kenya. African Crop Science Journal. 9: 279-285.

Kinyua Z M, Smith JJ, Odou GI, Wachira JN (1998) Increasing the availability of disease-free potato seed tubers to smallholder farmers in Kenya. p. 494-498. In: Akoroda MO, Ngeve JM (eds) Proceedings of the 8th Triennial Congress of the International Symposium for Tropical Root Crops-African Branch, 11-17June 1998, Cotonou, Benin. ISTRC-AB, Lilongwe, Malawi.

Kunze $\mathrm{G}$ (2004) The $\mathrm{N}$ terminus of bacterial elongation factor Tu elicits innate immunity in Arabidopsis plants. Plant Cell. 16: 3496-3507.

Laferriere LT, Helgeson JP, Allen C (1999) Fertile Solanum tuberosum + Solanum commersonii somatic hybrids as sources of resistance to bacterial wilt caused by Ralstonia solanacearum. Theor Appl Genet. 98: 1272-1278.

Lebeau A, Gouy M, Daunay MC, Wicker E, Chiroleu F, Prior P, Frary A, Dintinger J (2013) Genetic mapping of a major dominant gene for resistance to Ralstonia solanacearum in eggplant. Theor Appl Genet. 126:143-158.

Lebeau A, Daunay MC, Frary A, Palloix A, Wang JF, Dintinger $J$ et al. (2011) Bacterial wilt resistance in tomato, pepper, and eggplant: genetic resources respond to diverse strains in the Ralstonia solanacearum species complex. Phytopathology. 101: 154-165.

Lemaga B, Kakuhenzire R, Kassa B, Ewell PT, Priou S (2005) Integrated control of potato bacterial wilt in eastern Africa: the experience of African Highlands Initiative. p. 145-157. In: Allen C, Prior P, Hayward AC (eds) Bacterial Wilt Disease and the Ralstonia solanacearum Species Complex. American Phytopathological Society, St. Paul, MN, USA.

Lemaga B, Kanzikwera R, Kakuhenzire R, Hakiza JJ, Maniz G (2001) The effect of crop rotation on bacterial wilt incidence and potato tuber yield. African Crop Science Journal. 9: 257-266.

Liang C, He L (2002) Transformation of anti-microbial protein encoded by gene AP1 and the mediated resistance to bacterial wilt of transgenic potato. J Plant Prot. 93:236240.

Lopes CA, Melo PE, Rossato M, Pereira AS (2018) Breeding potatoes for resistance to bacterial blight in Brazil: a quick review in face of a more effective screening protocol. Horticultura Brasileira 36: 6-12.

Lopez MM, Biosca EG (2005) Potato bacterial wilt management: New prospects for an old problem.p.205224. In: Allen C, Prior P, Hayward AC (eds) Bacterial Wilt Disease and the Ralstonia solanacearum Species Complex. American Phytopathological Society, St. Paul, MN, USA.

Low JW (1997) Potato in south-western Uganda. Threats to sustainable production. African Crop Science Journal. 5: 295-412.

Mangin B, Thoquet P, Olivier J, Grimsley NH (1999) Temporal and multiple quantitative trait locianalyses of resistance to bacterial wilt in tomato permit the resolution of linked loci. Genetics 151:1165-1172.

Bulletin 13: 1-6. Centro Internacional de la Papa, Lima, Peru. 
Messiha NAS (2006) Bacterial wilt of potato (Ralstonia solanacearum race 3, biovar 2): Disease management,

Michel VV, Mew TW (1998) Effect of a soil amendment on the survival of Ralstonia solanacearum in different soils. Phytopathology. 88:300-305

Milling A, Meng F, Denny TP, Allen C (2009) Interactions with hosts at cool temperatures, not cold tolerance, explain the unique epidemiology of Ralstonia solanacearum race 3 biovar 2. Phytopathology. 99:1127-1134.

Montanelli C, Stetanini FM, Chiari A, Chiari T Niscari G (1995) Variability in the response to Pseudomonas solanacearum of transgenic lines of potato carrying a cecropins gene analogue. Potato Res. 38: 371-378.

Nakajima H, Muranaka T, Ishige F, Akutsu K, Oeda K (1997) Fungal and bacterial disease resistance in transgenic plants expressing human lysozyme. Plant Cell Rep. 16:674-679.

Narancio R, Zorrilla P, Robello C, Gonzalez M, Vilaró F, Pritsch C, et al. (2013). Insights on gene expression response of a characterized resistant genotype of Solanum commersonii Dun. against Ralstonia solanacearum. Eur J Plant Pathol. 136: 823-835.

Patil UV, Gopal J, Singh BP (2012) Improvement for bacterial wilt resistance in potato by conventional and biotechnological approaches. Agric Res. 1:299-316.

Pianzzola MJ, Zarantonelli L, González G, Franco Fraguas L, Vázquez A (2005) Genetic, phytochemical and biochemical analyses as tools for biodiversity evaluation of wild Solanum commersonii accessions. Biochem Syst Ecol. 33:67-78.

Pradhanang PM (1999) Transmission of Ralstonia solanacearum through drainage water. Bacterial Wilt Newsletter, 16, 5-7. Centro Internacional de la Papa, Lima Peru.

Prior P, Fegan M (2005) Recent developments in the phylogeny and classification of Ralstonia solanacearum. Acta Horticulturae. 695: 127-136.

Priou S, Gutarra L, Aley P (1999) Highly sensitive detection of Ralstonia solanacearum in latently infected potato tubers by post enrichment ELISA on nitrocellulose membrane. EPPO/OEPP Bulletin. 29: 117-125.

Priou S, Salas C, Mendiburu F, Aley P, Gutarra L (2001) Assessment of latent infection frequency in progeny tubers of advanced potato clones resistant to bacterial wilt: A new selection criterion. Potato Research. 44: 359 373.

Qian YL, Wang XS, Wang DZ, Zhang LN, Zu CL, Gao ZL, Zhang HJ, Wang ZY, Sun XY, Yao DN (2013) The detection of QTLs controlling bacterial wilt resistance in tobacco ( $N$. tabacum L.). Euphytica. 192:259-266.

Rowe PR, Sequeira I (1972) Development of potato clones with resistance to bacterial wilt. p. 206-211. In: French ER (ed) Prospects for the potato in the developing world. Centro Internacional de la Papa, Lima, Peru.

Schmiediche P (1985a) Breeding bacterial wilt (Pseudomnas solanacearum) resistant germplasm. p. 45-55. Present and future strategies for potato breeding and improvement. Report of the XXVI planning conference. December12-14 1983. Centro Internacional de la Papa, Lima, Peru.

Schmiediche P (1988) Breeding for resistance to Pseudomonas solanacearum. (P. 19-27). Bacterial diseases of the potato. In: Report of the Planning Conference on Bacterial Diseases of the Potato 1987. Centro Internacional de la Papa, Lima, Peru. 1988. pathogen survival, and possible eradication. Ph.D. Thesis, Wageningen University, The Netherlands.

Schmiediche P (1996) Problems and prospects of breeding for bacterial wilt resistance in potato. Pokhara: Lumle Agriculture Research Centre, 31-38 .p

Schmiediche P, Martin C (1986) The use of wild species in breeding for resistance to bacterial wilt (Pseudomonas solanacearum). American Potato Journal 63:453.

Seal SE, Taghavi M, Fegan N, Hayward AC, Fegan M (1999) Determination of Ralstonia (Pseudomonas) solanacearum rDNA subgroups by PCR tests. Plant Pathology 48: 115120.

Sequeira L (1979) Development of resistance to bacterial wilt derived from Solanum phureja. In Developments in control of potato bacterial diseases (pp. 55-62). Centro Internacional de la Papa, Lima, Peru.

Sequeira L, Rowe PR (1969) Selection and utilization of Solanum phureja clones with high resistance to different strains of Pseudomonas solanacearum. Am Potato J. 46: 451-462.

Shekhawat GS, Chakrabarti SK (1993) Integrated management of potato bacterial wilt. p. 87-93. In: Hardy $B$, French ER (eds) Integrated management of bacterial wilt. Proceedings of an International Field Workshop, 1116 October 1993, New Delhi, India. Centro Internacional de la Papa, Lima, Peru.

Silveira J, Duarte V, Moraes M, Lopes C, Fernandes J, Barni V (2007) Epidemiological analysis of clones and cultivars of potato in soil naturally infested with Ralstonia solanacearum biovar 2. Fitopatologia Brasileira. 32: 181188.

Siri MI, Galván GA, Quirici L, Silvera E, Villanueva P, Ferreira F, Fraguas LF, Pianzzola MJ (2009) Molecular marker diversity and bacterial wilt resistance in wild Solanum commersonii accessions from Uruguay. Euphytica. 165:371-382.

Siri MI, Sanabria A, Pianzzola MJ (2011) Genetic diversity and aggressiveness of Ralstonia solanacearum strains causing bacterial wilt of potato in Uruguay. Plant Dis. 95, 1292-1301.

Smith EF (1896) A bacterial disease of tomato, pepper, eggplant, and Irish potato (Bacillus solanacearum nov. sp.) U.S. Dep Div Veg Phys Path Bull. 12:1-28.

Smith JJ, Offord LC, Holderness M, Saddler GS (1995) Genetic diversity of Bulkholderia solanacearum (Syn. Pseudomonas solanacearum) race 3 in Kenya. Applied and Environmental Microbiology. 61: 4263-4268.

Sunaina V, Kishore V, Shekhawat GS (1989) Latent survival of Pseudomonas in potato tubers and weeds. Journal of Plant Disease and Protection. 96: 361-364.

Vleeshouwers VG, Oliver RP (2014) Effectors as tools in disease resistance breeding against biotrophic, hemibiotrophic, and necrotrophic plant pathogens. Molecular Plant-Microbe Interactions. 27: 196-206.

Vunnam S, Juvvadi P, Merrifield RB (1997) Synthesis and antibacterial action of cecropin and pro-arg-rich peptides from pig intestine. J Peptide Res. 49:59-66

Wang JF, Olivier J, Thoquet P, Mangin B, Sauviac L, Grimsley $\mathrm{NH}$ (2000) Resistance of tomato line Hawaii7996 to Ralstonia solanacearum Pss4 in Taiwan is controlled mainly by a major strain-specific locus. Molecular PlantMicrobe Interactions. 13: 6-13. 
Watanabe KN, El-Nashaar HM, Iwanaga M (1992) Transmission of bacterial wilt resistance by first division restitution (FDR) 2n pollen via 49929 crosses in potatoes. Euphytica. 60:21-26

Yabuuchi E, Kosako Y, Yano I, Hotta H, Nishiuchi Y 1995 Transfer of two Burkholderia and an Alcaligenes species to Ralstonia genus nov.: proposal of Ralstonia pickettii (Ralston, Palleroni and Douderoff 1973) comb.nov., Ralstonia solanacearum (Smith 1896) comb. nov. and
Ralstonia eutropha (Davis 1969) comb. nov. Microbiology and Immunology. 39: 897-904.

Zipfel C, Oldroyd, GED (2017) Plant signalling in symbiosis and immunity. Nature. 543: 328-336.

Zipfel C, Kunze G, Chinchilla D, Caniard A, Jones JDG, Boller T, et al. (2006) Perception of the bacterial PAMP EF-Tu by the receptor EFR restricts agrobacterium-mediated transformation. Cell 125: 749-760. 